\title{
Free Movement of Persons in the EUv. in the EEA: of Effect-Related Homogeneity and a Reversed Polydor Principle
}

\author{
Christa Tobler*
}

\section{Introduction}

When the European Economic Area (EEA) Agreement ${ }^{1}$ was concluded in the early 199os, it reflected, in the fields covered, the state of the law of the then Community law. This also applied in the field of the free movement of persons. Since then, both EEA and EU law in this field have developed further, though with certain marked differences. Most notably, in the Union the Treaty revision of Maastricht led to the introduction of Union citizenship on the Treaty level. Subsequently, Directive 2004/38 $8^{2}$ was adopted as a further development of the law on former free movement, on the one hand, and as a Union citizenship instrument, on the other hand. This double nature of the Directive and the fact that there is no concept corresponding to Union citizenship in the EEA Agreement led to certain challenges within the EEA, when faced with the demand of the EU that the Directive should be incorporated into EEA law. In fact, it was difficult to convince some of the EEA/European Free Trade Association (EFTA) States to agree to such incorporation. When eventually it was incorporated, this was done with certain reservations.

Today, it can be stated that the EEA and the EU rules are identical with respect to the market access rights of economic agents (e.g. the right of migrant workers to be employed in another contracting State without

* Professor of European Union Law, Europa Institutes of the Universities of Basel (Switzerland) and Leiden (The Netherlands).

1 European Economic Area Agreement of 2 May 1992. For a consolidated version of the Agreement that incorporates subsequent changes, see http://www.efta.int/Legal-Text/EEAAgreement-1327.

2 Directive 2004/38/EC of the European Parliament and of the Council of 29 April 2004 on the right of citizens of the Union and their family members to move and reside freely within the territory of the Member States amending Regulation (EEC) No 1612/68 and repealing Directives 64/221/EEC, 68/36o/EEC, 72/194/EEC, 73/148/EEC, 75/34/EEC, 75/35/EEC, 9o/364/EEC, 9o/365/EEC and 93/96/EEC, OJ 2004 L 158/77, OJ L 158, 30.4.2004, p. 77-123. 
discrimination on grounds of nationality and without restrictions). In contrast, it is debated whether and to what extent the incorporation of Directive 2004/38 into the EEA legal system is limited for those purposes. Doubts have arisen notably in the context of recent case law of the EFTA Court (which deals with EEA law matters arising in the three EEA/EFTA States Iceland, Liechtenstein and Norway) in the context of travel and residence rights and of family reunification.

This issue forms the subject matter of the present contribution, which explores the differences in the legal regime on the free movement of persons in the EU as compared to the EEA. The contribution begins with a brief description of the legal framework of the incorporation of Directive 2004/38 into EEA law (section II.). In its main part, it then turns to the EFTA Court's case law on the possible limits of that incorporation (section III.) and, more generally, on the meaning of the Directive in the EEA context (section IV.). A final part will summarise the findings and ask what they mean in other contexts, including notably that of the withdrawal of the United Kingdom of Great Britain and Northern Ireland from the EU ("Brexit") (section v.).

\section{The Incorporation of Directive 2004/38 into EEA Law: Legal Framework}

Through the EEA Agreement, the participating EFTA States ${ }^{3}$ associate themselves to EU law in a number of important areas, the core of which is the Union's internal market law. With respect to persons, this included from the beginning not only the (then Community) rules on the free movement of persons and services, but also the movement and residence rights for the

3 This includes all EFTA States except Switzerland. Whilst the Swiss Government wanted the country to join and participated very actively in the negotiation of the EEA Agreement, a popular vote held in 1991 yielded a negative result with respect to membership; see Nell, P.G. (2012). Suisse-Communauté Européenne. Au coeur des négotiations sur l'Espace économique européen. Paris: Economica. Following the vote, Switzerland continued on its previous path of concluding sectoral agreements with the Communities and the Union; for a brief introduction in the English language, see Oesch, M. (2018). Switzerland and the European Union. General Framework. Bilateral Agreements. Autonomous Adaptation. Zurich/St.Gallen and Baden-Baden: Dike/Nomos. For more details, e.g. Oesch M. (2015). Europarecht. Band I Grundlagen, Institutionen, Verhältnis Schweiz-EU, Berne: Stämpfli; Cottier T., Diebold, N., Kölliker, I., Liechti-McKee, R., Oesch, M., Paysova, T. and Wüger, D. (2014). Die Rechtsbeziehungen der Schweiz und der Europäischen Union. Berne: Stämpfli, and Tobler, C. and Beglinger, J. (2013). Grundzüge des bilateralen (Wirtschafts-)Rechts. Systematische Darstellung in Text und Tafeln (2 vols.).Zurich/St.Gallen: Dike. 
economically non-active under what was then Directives 9o/364, ${ }^{4} 90 / 365^{5}$ and $93 / 96 .{ }^{6}$ In this as in other fields, Community law developed further following the signing of the EEA Agreement. For this situation, the EEA Agreement envisages a dynamic system of updating the EEA acquis: if new EU law falls within a field covered by the EEA Agreement, the EEA Joint Committee will decide on its incorporation into EEA law. Should this decision not be taken, the consequence may be that the relevant part of the EEA Agreement is suspended (Article $102 \mathrm{EEA}) .^{7}$

This mechanism also came into play with regard to Directive 2004/38, which was incorporated into Annex v to the EEA Agreement, concerning the free movement for workers, and into Annex VIII, concerning freedom of establishment, by Decision of the EEA Joint Committee 158/2007 ("Joint Committee Decision" or "JCD"). ${ }^{9}$ For these purposes, the Directive's geographic scope had to be broadened (namely to include the EEA/EFTA States) and its wording had to be adapted (e.g. to be read as referring, for the purposes of EEA law, not to "Union citizens" but rather to "national(s) of [EU] Member States and EFTA States", Article 1(1)(c) JCD). In addition, there was the problem that the concept of EU citizenship does not apply in the EEA/EFTA States. For that reason, the EEA/EFTA States were not enthusiastic about incorporation. However, the EU refused an approach whereby the provisions of the Directive that are linked to EU citizenship would have been excluded from incorporation into EEA law. Instead, the parties agreed to a compromise under which the full text of the Directive was incorporated, though with certain limits regarding their interpretation and application.

4 Council Directive 9o/364/EEC of 28 June 1990 on the right of residence, OJ L 180, 13.7.1990, p. 26-27 (no longer in force).

5 Council Directive 9o/365/EEC of 28 June 1990 on the right of residence for employees and self-employed persons who have ceased their occupational activity, OJ L 180, 13.7.1990, p. 28 29 (no longer in force).

6 Council Directive 93/96/EEC of 29 October 1993 on the right of residence for students, OJ L $317,18.12 .1993$, p. 59-6o (no longer in force).

7 For the incorporation procedure, see e.g. Baur G. (2015). Decision-Making Procedure and Implementing of New Law, as well as Suspension of Parts of the EEA Agreement: Disputes About Incorporation, Consequences of Failure to Reach Agreement and Safeguard Measures. Both in: Baudenbacher C., ed., The Handbook of EEA Law. Cham: Springer, pp. 45-67 and pp. 6983 , respectively.

8 See already Tobler, C. (2013). Bikers Are(n't) Welcome. (Jan Anfinn Wahl ./. The Icelandic State, EFTA Court, judgment of 22 July 2013, E-15/12). European Law Reporter, pp. 246-255, 250 et seq.

9 EEA Joint Committee, Decision No 158/2007 of 7 December 2007 amending Annex V (Free movement of workers) and Annex VIII (Right of establishment) to the EEA Agreement. 
First, the JDC circumscribes the fields where the incorporation takes effect. According to Articles 1 and 2 JCD, the Directive "shall apply, as appropriate, in the fields covered by this Annex", i.e. the free movement for workers under Annex V and that of freedom of establishment under Annex VIII. However, it should be noted that these Annexes concern not only the legal position of migrant workers and the self-employed, respectively, with the nationality of an EEA State, but also that of their family members as defined in the Directive. Further, Annex VIII also touches upon services and includes rules on the movement and residence of non-economic agents. Overall, this means that not only in the framework of EU law but also in that of EEA law, Directive 2004/38 applies to the movement of natural persons in a rather broad sense (workers, the self-employed, service providers and recipients, and non-economically active persons under certain conditions), though according to the JCD only "as appropriate". As will be seen infra (section IV.), the EFTA Court appears to have given a surprising meaning to this latter term.

Second, the Contracting Parties noted in the preamble to the JCD that the concept of Union citizenship is not included in, and immigration policy is not part of, the EEA Agreement. This is elaborated on in a Joint Declaration. With reference to EU citizenship, it states:

The concept of Union Citizenship as introduced by the Treaty of Maastricht $[\ldots]$ has no equivalent in the EEA Agreement. The incorporation of Directive 2004/38/EC into the EEA Agreement shall be without prejudice to the evaluation of the EEA relevance of future EU legislation as well as future case law of the European Court of Justice based on the concept of Union Citizenship. The EEA Agreement does not provide a legal basis for political rights of EEA nationals.

Burke et al..$^{10}$ note that, as a result of its incorporation into EEA law, the Directive 2004/38 now applies in two divergent legal contexts (namely EU law and EEA law). For practical purposes, the challenge lies in the fact that when the EEA Joint Committee limited the application of the Directive to the (broad) scope of the two annexes as just described and at the same time stated that EU citizenship and immigration policy are not part of EEA law, it consciously left

10 Burke, C., Ísberg Hannesson, Ó. and Bangsund, K. (2017). Chapter 12: Schrödinger's Cake? Territorial Truths for Post-Brexit Britain. In: M. Kuijer and W. Werner, eds., Netherlands Yearbook of International Law 2016: The Changing Nature of Territoriality in International Law, The Hague: T.M.C. Asser Press, pp. 287-312, p. 309. 
it to the courts to decide through interpretation what this means in concrete terms. In other words, the letter of EEA law is not clear on this matter.

The following part deals with case law on Directive 2004/38 in the EEA context and on the meaning of the reservation in the JCD with respect to Union citizenship, in the latter context more specifically on the meaning of the second sentence in the above quote from the Joint Declaration ("The incorporation of Directive 2004/38/EC into the EEA Agreement shall be without prejudice to the evaluation of the EEA relevance of future EU legislation as well as future case law of the European Court of Justice based on the concept of Union Citizenship."). At the time of writing, there is no case law yet of the Court of Justice of the European Union (CJEU) on either the incorporation of Directive 2004/38 into the EEA legal acquis or on the meaning of the Directive in this specific context." In contrast, there are a number of EFTA Court judgments on Directive 2004/38 in the EEA context. Of these, only one addresses the substantive meaning of the reservation with respect to Union citizenship, namely Wahl, ${ }^{12}$ and then only in an obiter dictum.

\section{The Meaning of the Reservation according to the EFTA Court's Obiter Dictum in Wahl}

The Wahl case concerned the limitations to the right of entry and residence of persons with the nationality of an EEA State under Article 27 of Directive 2004/38. The EFTA Court held that the above-mentioned reservation cannot be relevant in this context. In the present writer's opinion, that is correct, as the case concerned a provision on limitations to free movement that simply codified CJEU case law on the previous derogation rules, both of which had already been part of EEA law before the incorporation of Directive 2004/38 and neither of which relates specifically to Union citizenship. In fact, Wahl is

11 In the EU law context, this could notably be an action for annulment under Art. 263 TFEU of the decision of the EU to agree to the incorporation of the JCD (compare, in a different context, CJEU, judgment of 27 February 2014, Case C-656/11 UKv Council) or a preliminary ruling under Art. 267 TFEU on an EEA matter arising in the territory of an EU Member State. In the latter context, an example of a matter falling within the jurisdiction of the CJEU would be an Icelandic national who faces problems when wishing to exercise EEA free movement rights in Spain (or in any other EU Member State). Conversely, where an EEA matter arises on the territory of an EEA/EFTA State, it falls within the jurisdiction of the national courts of that state and of the EFTA Court.

12 EFTA Court, judgment of 9 December 2013, Case E-15/12 Jan Anfinn Wahl $v$ The Icelandic State, [2013] EFTA Court Reports 534. 
simply a successor to the European Economic Community (EEC) free movement for workers case of Van Duyn. ${ }^{13}$

Even so, the EFTA Court addressed the incorporation of the Directive into EEA law and the meaning of the reservation as follows (Wahl, para. 74 et seq.):

The Directive was incorporated into the EEA Agreement by the adoption of Joint Committee Decision No 158/2007 ("the Decision"). According to the Decision, the concept of 'Union Citizenship' and immigration policy are not included in the Agreement. That is further stipulated in the accompanying Joint Declaration by the Contracting Parties ("the Declaration"). However, these exclusions have no material impact on the present case. Nevertheless, the impact of the exclusions must be assessed on a case-by-case basis and may vary accordingly. In this regard, it must be noted that, as is apparent from Article 1(a) and recital 3 in its preamble, the Directive aims in particular to strengthen the right of free movement and residence of EEA nationals [...]. To this end, it lays down the conditions governing the exercise of the right of free movement and residence within the territory of the EEA. The impact of the exclusion of the concept of citizenship has to be determined, in particular, in cases concerning Article 24 of the Directive which essentially deals with the equal treatment of family members who are not nationals of a Member State and who have the right of residence or permanent residence. [...].

In the present writer's analysis of the Wahl judgment, the EFTA Court's statements with regard to Article 24 in the EEA context might be the point where the Polydor principle enters EEA law. ${ }^{14}$ According to this principle, provisions of agreements concluded by the EU with non-Member States are not automatically to be interpreted in the same manner, even if they are very similar or even identical; rather, relevant differences in the context may lead to a different interpretation. Weiss \& Kaupa ${ }^{15}$ observe more generally that free movement rights under EEA law may have to be interpreted differently from EU law if the legal or factual situation differs. In the present context, this might mean that certain provisions of Directive 2004/38, including in particular Article 24, though

13 CJEu, judgment of 4 December 1974, Case 41/74 Yvonne van Duyn v Home Office, ECLI:EU:C:1974:133. See on this point Tobler, C. (2013). Bikers Are(n't) Welcome, cit., 249 et seq.

14 Tobler, C. (2013). Bikers Are(n't) Welcome, cit., p. 252.

15 Weiss, F. and Kaupa, C. (2014).European Union InternalMarket Law. Cambridge:Cambridge University Press, p. 24. 
formally part of both EU law and EEA law, might not have the same relevance or meaning in the two legal orders. Indeed, it could even mean that the incorporation of Directive 2004/38 into EEA law implies certain substantive carveouts, an approach that could be useful also in other contexts of the EU's external relations, including notably the EU-Swiss Agreement on the free movement of persons. ${ }^{16}$ This has, however, not been confirmed through case law so far.

Other commentators on the EFTA Court's Wahl decision were more critical. Fredriksen \& Franklin ${ }^{17}$ thought that the EFTA Court's reference to "in particular, Art. 24 of the Directive", to the exclusion of other aspects, meant that the wind was already seemingly snatched out of the Joint Declaration's sails. In this context, it is interesting to note the Norwegian Government's argument before the EFTA Court that Directive 2004/38 has a more limited scope under EEA law than under EU law, due to the fact that Union citizenship is not part of the former. However, the following parts of this contribution will show that that is not the gist of subsequent case law of the EFTA Court. Whilst the expectation that identical provisions might not have the same meaning under EU and EEA law has been confirmed, this is in a rather different manner than expected by the present writer in her annotation of the Wahl judgment. Indeed, the result of more recent EFTA Court case law appears to be, not that of limiting the meaning of Directive 2004/38 under EEA law but, on the contrary, of broadening it beyond that applicable under EU law, based on a rather particular understanding of homogeneity.

None of these other decisions applies the reservation, and none elaborates on its meaning. On the contrary: several commentators are of the opinion that, in

16 Tobler, C. (2013). Bikers Are(n't) Welcome, cit., p. 253. More specifically, this would mean that certain matters, in the context of EU law, are clearly linked to Union citizenship, though formally part of the Directive also in the EEA context, would in fact not be part of EEA law, e.g. the right to equal treatment of the economically non-active with respect to social assistance (see also infra, footnote 25). Similarly, Fredriksen and Franklin thought that where the CJEU bases its decisions on these Union citizenship provisions or gives a "citizenship reading" of worker's rights under EU law, the same direct methods will not be possible under EEA law. As an example, they mention job-seekers' rights to equal treatment under Art. 45 TFEU; Fredriksen, H.H. and Franklin, C.N.K. (2015). Of pragmatism and principles: The EEA Agreement 20 years on. Common Market Law Review 52(3), pp. $629-684,640$.

Idem, p. 643 . 
terms of their substantive finding, certain of these decisions are, in fact, based on elements of Union citizenship, thereby going beyond the limits of EEA law. It is submitted that at least one of these decisions is unproblematic, whilst two further decisions indeed raise a number of questions. ${ }^{18}$

\section{IV.1 Unproblematic in the Present Writer's Opinion: Clauder}

Clauder $^{19}$ was the first EFTA Court decision on Directive 2004/38 in the EEA context, handed down shortly before Wahl, without elaborating on the reservation in the Joint Declaration with respect to Union citizenship. The case concerns the right of permanent residence of family members of EEA nationals under Article 16 of the Directive. Mr Clauder, a German national living as a pensioner in Liechtenstein, drew old age pensions from Germany and Liechtenstein and supplementary social welfare benefits in Liechtenstein. Mr Clauder's wife, a German national, lived in Germany at the time of their marriage. The Liechtenstein authorities based their refusal of family reunification on the argument that Mr Clauder could not prove that he had sufficient financial resources for himself and his wife without having recourse to social welfare benefits. The case led to a request for an advisory opinion to the EFTA Court under Article 34 of the Agreement between the EFTA States on the Establishment of a Surveillance Authority and a Court of Justice (ESA/Court Agreement). ${ }^{20}$

It should be noted that even though Article 16 of the Directive mentions the right to permanent residence for family members in para. 2 (a fact that is sometimes overlooked in comments on the Clauder decision), this relates specifically and exclusively to "family members who are not nationals of a Member State". These are given a right to permanent residence if they have legally resided with the Union citizen in the host Member State for a continuous period of five years. In contrast, no mention is made of family members whose nationality is of a Member State, as was the case with Ms Clauder. It is therefore not clear from the wording of the Directive whether such persons, too, must fulfill the residence condition (which Ms Clauder did not), possibly

18 One of the more recent decisions of the EFTA Court is not discussed below because, although it refers to Directive 2004/38, the facts of the case appear not to be covered by that Directive; EFTA Court, judgment of 13 November 2019, Case E-2/19 D and E, https:// eftacourt.int/download/2-19-judgment/?wpdmdl=6340.

19 EFTA Court, judgment of 8 April 2013, Case E-4/11 Arnulf Clauder, [2011] EFTA Court Reports, 216.

201994 Agreement between the EFTA States on the Establishment of a Surveillance Authority and a Court of Justice, OJ 1994 L 344/1, available at www.efta.int. 
combined with the condition of sufficient means and comprehensive health insurance.

According to the EFTA Court, there are no such conditions for EU nationals and there is a right to immediate permanent residence, even where the family member will be claiming social welfare benefits. As Franklin ${ }^{21}$ notes, the EFTA Court made no direct reference to CJEU citizenship case law. The respective reservation is not mentioned in the judgment, and the JCD appears only in the part where the EFTA Court describes the EEA legal context (Clauder, para. 5). According to Wennerås, ${ }^{22}$ the Court "dodged the issue", relying instead on elements such as the right to protection of family life and the strengthening of free movement rights (Clauder, para. 33 et seq.).

Opinions with respect to the acceptability of the EFTA Court's approach differ. According to Fløistad, ${ }^{23}$ the EFTA Court in Clauder took an innovative step towards free movement rights for economically inactive citizens in the EEA Agreement, in fact comparable to the CJEU citizenship case law in the EU legal order. Similarly, Jay ${ }^{24}$ writes about an active, pro-integrationist stance of the EFTA Court and suggests that in Clauder the Court has essentially assimilated nationality of an EEA/EFTA State with EU citizenship for the purposes of free movement and residence. In Jay's view, no other conclusion is tenable if the homogeneity of the internal market is to be maintained in a manner which secures fair and effective legal rights, though this can be seen to come at the cost of legal certainty. Still in the same vein, Einarsson ${ }^{25}$ considers the Court's (implicit) view that the EEA adaptations (i.e. with respect to the scope and the interpretation of the law) have no impact on the interpretation of the Directive well founded, as otherwise there would be very major deviations from the very wording of these adaptations.

21 Franklin, C.N.K. (2017). Square Pegs and Round Holes: The Free Movement of Persons Under EEA Law. Cambridge Yearbook of European Legal Studies 19, pp. 165-186, p. 177.

22 Wennerås, P. (2018). Article 6 Homogeneity. In: F. Arnesen, H.H. Fredriksen, H.P. Graver, O. Mestad, and C. Vedder, eds., Agreement on the European Economic Area:EEA Agreement. A commentary. C.H. Beck, Munich, pp. 209-248, para. 15 .

23 Fløistad, F. (2018). Article 28 Free movement of workers. In: F. Arnesen, F., H.H. Fredriksen, H.H., H.P. Graver, H.P., O. Mestad, O. and C. Vedder C., eds., Agreement on the European Economic Area, cit., pp. 369-385, para.15.

24 Jay, M.A. (2012). Homogeneity, the free movement of persons and integration without membership: mission impossible?. Croatian Yearbook of European Law and Policy 8, pp. $77-116,87$ et seq.

25 Einarsson, Ó.J. (2018). Article $3_{1}$ Freedom of establishment, in Wennerås, P. (2018). Article 6 Homogeneity. In: F. Arnesen, F., H.H. Fredriksen, H.H., H.P. Graver, H.P., O. Mestad, O. and C. Vedder C., eds., Agreement on the European Economic Area, cit., pp. 400-420, para. 38 . 
In contrast, the authors writing for the law firm Simonsen Vogt Wiig AS ${ }^{26}$ opine that, according to the wording of the Directive, family members who do not fulfil the requirements for permanent residence pursuant to Article 16, para. 2, of the directive may only be granted a right of residence pursuant to Article 7, para. 1, letter c, in conjunction with Article 7, para. 1, letter b, of the Directive. In effect, this means that according to this view Article 16, para. 2, is relevant also for family members with the nationality of an EU Member State.

In the present writer's view, the legal situation in Clauder is special in that the EFTA Court was faced with the gap in Article 16 of Directive 2004/38 with respect to family members with an EU nationality. It was, moreover, a gap that had not yet been filled by the CJEU in its case law. There was, therefore, no previous CJEU case law which the EFTA Court could or should have taken in account. Rather, the situation was one of "first go" for the EFTA Court, which gave it the chance to shape the interpretation of EEA law, at least for the time being (i.e. awaiting what the CJEU would make of it once it would have the issue before it).

Did the EFTA Court fill the gap by using Union citizenship elements derived from CJEU case law on Union citizenship dating from after 7 December 2007, contrary to the reservation in the Joint Declaration? It is submitted that is not the case: Where the EFTA Court, in the relevant parts of the judgment, relies on CJEU case law, it does so with respect to the basic right to family unification. Did the Court otherwise rely on Union citizenship, outside the limits of the reservation? It is true that under EU law, entitlement to social assistance for the economically non-active as such is historically linked to Union citizenship (i.e. it has developed through cJEU Union citizenship case law). ${ }^{27}$ Insofar, one may argue that the fact that Directive 2004/38 does not maintain these conditions, for the economically non-active, in the context of the newly created status of permanent residence is a consequence of Union citizenship, rather than a "mere" further development of the free movement aspects of previous law. However, that cannot be relevant under the Union citizenship reservation, which only relates to the evaluation of the E EA relevance of future

26 Advokatfirmaet Simonsen Vogt Wiig AS (2016). Legal study on Norway's obligations under the EU Citizenship Directive 2004/38/EC, available at https:/www.udi.no/globalassets/ global/forskning-fou_i/annet/norways-obligations-eu-citizenship-directive.pdf, p. 123.

27 On this issue e.g. Tobler, C. (2015). Auswirkungen einer Übernahme der Unionsbürgerrichtlinie für die Schweiz - Sozialhilfe nach bilateralem Recht als Anwendungsfall des Polydor-Prinzips. In: A. Epiney, and T. Gordzielik, eds., Personenfreizügigkeit und Zugang zu staatlichen Leistungen / Libre circulation des personnes et accès aux prestations étatiques. Zurich/Basel/Geneva: Schulthess, 55-82. 
EU legislation as well as future CJEU case law based on the concept of Union Citizenship.

More generally, it should be noted that Mr Clauder's personal right to reside in Liechtenstein, in spite of the fact that he was in receipt of social welfare assistance, was not in dispute. Rather, the case exclusively concerned the right to family reunification and in this vein Ms Clauder's residence rights.

Overall, the present writer's conclusion is that Clauder is in no way problematic, but rather represents a sensible approach to filling the gap in Article 16 of the Directive 2004/38. After all, in a situation where the Directive clearly states certain conditions for third country family members only, it is quite legitimate to assume that the legislator did not wish the same conditions to apply to EU nationals, and it would be unreasonable to assume that EU family members would not enjoy permanent residence at all.

\section{IV.2 From Clauder to Gunarsson and Jabbi: a Very Particular Understanding of Homogeneity}

Compared to Clauder, the situation in the subsequent cases of Gunnarsson ${ }^{28}$ and $J a b b i^{29}$ was different, as the EFTA Court in its judgment ruled on the meaning of the provisions of Directive 2004/38 in contexts that had already been addressed by the CJEU in its case law. Accordingly, the EFTA Court was bound by the homogeneity principle under Article 6 EEA.

According to this principle, the provisions of the EEA Agreement, in so far as they are identical in substance to corresponding rules of EU law shall be interpreted in conformity with the relevant rulings of the CJEU given prior to the date of signature of the EEA Agreement. However, the EFTA Court has held generally that it does not consider this limitation in terms of time - i.e. relevance only of CJEU judgments given prior to the date of signature of the EEA Agreement - useful. Rather, in the interest of the effectiveness of EEA law, the EFTA Court goes beyond this date and also takes into account subsequent case law. ${ }^{30}$

28 EFTA Court, judgment of 27 June 2014, Case E-26/13 The Icelandic State and Atli Gunnarsson, [2014] EFTA Court Reports 254.

29 EFTA Court, judgment of 26 July 2017, Case E-28/15 Yankuba Jabbi v The Norwegian Government, [2016] EFTA Court Reports 573 .

30 For example, EFTA Court, judgment of 5 April 2013, Case E-2/o6 EFTA Surveillance Authority $v$ Norway. In this case, commonly referred to as the Norwegian Waterfalls case, [2007] EFTA Court Reports 164, the EFTA Court stated (para. 59): "The principle of homogeneity enshrined in the EEA Agreement leads to a presumption that provisions framed identically in the EEA Agreement and the EC Treaty are to be construed in the same way." 
In academic writing, it has been noted that homogeneity does not have to be slavish but can be creative. ${ }^{31}$ As was already indicated, both Gunnarsson and Jabbi reflect a very particular type of creative homogeneity, where the EFTA Court consciously interprets EEA law differently from EU law, in order to achieve the same level of protection for EEA citizens as for EU citizens. Before these decisions were handed down, a hint of this approach could, perhaps, be found in an article by the former President of the EFTA Court, Carl Baudenbacher, entitled "The goal of homogeneous interpretation of the law in the European Economic Area. Two courts and two separate legal orders, but law that is essentially identical in substance." ${ }^{32}$

In the following sections, the facts and issues of the Gunnarsson and Jab$b i$ cases are described and the EFTA Court's judgments in these cases are discussed, again, in view of the reservation with respect to Union citizenship.

\section{IV.3 Gunnarsson and Jabbi: Facts and Issues}

According to Fredriksen \& Franklin, ${ }^{33}$ the Gunnarsson case represented the litmus test of the EFTA Court's approach with respect to the reservation in the above-mentioned Joint Declaration (more specifically: of the second sentence of the above quote). The case involved an Icelandic couple who had lived in Denmark for a certain time. Their income, which was taxed in Iceland, consisted of various pensions and benefits, including, among others, an employmentrelated pension of Mr Gunnarsson. He claimed that, for the purposes of taxation in Iceland, he should be allowed to use his wife's unused personal tax credit in respect of his income for the time during which he resided in Denmark. This was denied to him because, under the law in force at the time (which was subsequently amended), the transfer of a personal tax credit was only possible between taxpayers with unlimited tax liability in Iceland (essentially resident taxpayers) or where both spouses were in receipt of an Icelandic pension. None of this applied in the case at hand. Mr Gunnarsson demanded repayment of the income tax that he considered to have paid in excess. When refused, he brought an action to the relevant District Court. Both he and the Icelandic State appealed against this court's decision, whereupon the Icelandic

31 E.g. Timmermans, C. (2006). Creative Homogeneity. In: M. Johansson, N. Wahl, and U. Bernitz, eds., Liber amicorum in Honour of Sven Norberg: A European for all Seasons, Brussels: Bruylant, 471-484.

32 Baudenbacher, C. (2008). The goal of homogeneous interpretation of the law in the European Economic Area. Two courts and two separate legal orders, but law that is essentially identical in substance. The European Legal Forum 1-2008, I-22-31. 
Supreme Court turned to the EFTA Court for an advisory opinion. The Supreme Court's questions related to the applicability of Article $28 \mathrm{EEA}$ and/or Article 7 of Directive 2004/38 in circumstances as that at hand. In addition, the national court asked whether it is of any significance that the EEA Agreement does not contain a provision corresponding to Article $21 \mathrm{TFEU}$, on the free right to movement of Union citizens.

Before the EFTA Court, Iceland, Norway and EFTA Surveillance Authority (ESA) argued that Article 7 of Directive 2004/38 does not impose obligations on the home State and therefore cannot be applicable in case like Gunnarsson. Rather, in EU law - and only there - such obligations follow from Article 21 TFEU. Alternatively, Norway argued that if Article 7 of the Directive should entail rights in relation to the home State, it follows from the JCD that only economically active persons are included. In contrast, the European Commission was of the opinion that Mr Gunnarsson could rely on Article 7 of the Directive in order to claim equal treatment with residents of Iceland in relation to the pooling of personal tax credits with his spouse, based on the argument that the rights of free movement and residence envisaged by this provision would be set at nought if the home State could obstruct persons wishing to avail themselves of them.

The Jabbi case concerned the question of whether "Article 7(1)(b), cf. Article 7(2), of Directive 2004/38/EC confer derived rights of residence to a third country national family member of an EEA national who, upon returning from another EEA State, is residing in the EEA State in which the EEA national is a citizen" (Jabbi, para. 26). Mr Jabbi had married his Norwegian wife when she lived in Spain as an economically inactive person. From there they later returned to Norway. When Mr Jabbi's application for residence in that country was refused, he went to court which turned to the EFTA Court for help with the interpretation of Directive 2004/38.

Before the EFTA Court, the ESA argued that the scope of free movement rights granted to EFTA nationals should be the same as for EU nationals; further, that the lack of a citizenship concept in the EEA Agreement means that the Directive should be accorded a more important role in the EEA context and that its scope must therefore be broadened on the basis of the principle of effectiveness. The European Commission, interestingly, criticised previous CJEU case law (mentioned further below) and argued that it should not apply in the present context.

\section{IV.4 The EFTA Court's Decision in Gunnarsson}

In Gunnarsson, the Court mentions both the JCD and the accompanying Joint Declaration, acknowledging that "the incorporation of Directive 2004/ 
38 cannot introduce rights in to the EEA Agreement based on the concept of Union Citizenship". However, it then adds that "individuals cannot be deprived of rights that they have already acquired under the EEA Agreement before the introduction of Union Citizenship in the EU" (Gunnarsson, para. 80). This has to be seen against the background of the secondary law on movement and residence that applied before the incorporation of Directive 2004/38 into EEA law. In fact, the EFTA Court found that due to temporal aspects of the Gunnarsson case, both the former Directive 90/365 and the subsequent Directive 2004/38 were applicable. Noting that Directive 9o/365 - in contrast to Directive 2004/ 38 - does not explicitly mention a right of exit, the EFTA Court points out that taking up residence in another state presupposes a move from the EEA State of origin. From this, it concludes that Article 1 of Directive 9o/365 on the right of residence must be understood as also prohibiting the home State from hindering the person concerned from moving to another EEA State (Gunnarsson, para. 77).

In the present writer's opinion, so far, the judgment is easy to follow and logical, if understood literally as relating to the right of exit by crossing the national border. What follows is perhaps more surprising. Pointing out that the substance of Article 1 of Directive 9o/365 has been maintained in Article 7, para. 1, letter b, of Directive 2004/38, the Court finds that there is nothing to suggest that the latter provision must be interpreted more narrowly than the former with regard to a right to move within the EEA from the home State. On the contrary, according to recital 3 of its preamble, Directive 2004/38 aims in particular to strengthen the right of free movement and residence. Against this background, the EFTA Court concludes that "Article 1(1) of Directive 9o/ 365 and Article 7, para. 1, letter b, of Directive 2004/38 must be interpreted such that they confer on a pensioner who receives a pension due to a former employment relationship, but who has not carried out any economic activity in another EEA State during his working life, not only a right of residence in relation to the host EEA State, but also a right to move freely from the home EEA State. The latter right prohibits the home State from hindering such a person from moving to another EEA State. A less favourable treatment of persons exercising the right to move than those who remain resident amounts to such a hindrance. Furthermore, a spouse of such a pensioner has similar derived rights, cf. Article 1(2) of Directive 9o/365 and Article 7(1)(d) of Directive 2004/ 38, respectively." (Gunnarsson, para. 82).

The Court then elaborates on the meaning of the principle of equal treatment with respect to EEA direct tax law, thereby relying on CJEU case law on EU direct tax law (Gunnarsson, para. 84 et seq.). With respect to justification, the Court states that less favourable treatment of a pensioner and his wife who 
have exercised the right to move freely within the EEA is not compatible with Article 1(1) and (2) of Directive 9o/365 and Article 7(1)(b) and (d) of Directive $2004 / 38$, where the pension received by the pensioner constitutes all or nearly all of that person's income, unless objectively justified. However, the EFTA Court refuses to consider the arguments by Iceland based on the grounds of fiscal cohesion and the effectiveness of fiscal supervision (both arguments that often appear in tax cases), pointing out that such grounds are permitted neither under Directive 90/365 nor under Directive 2004/38.

In the analysis of Wennerås, ${ }^{34}$ the Court swept everything aside that it had said in Wahl in relation to the reservation in the Joint Declaration in relation to Union citizenship, resulting in an interpretation of EEA law that, on the level of secondary law, covers a field of law falling outside the Main Part of the EEA Agreement itself. Conversely, in the present writer's analysis, the reservation played no real role in the EFTA Court's decision. It is, however, true that the Court's approach is very particular in other respects.

With respect to the reservation, the decisive question is, again, whether the EFTA Court relied on Union citizenship case law of the CJEU that dates from after 7 December 2007. That is not the case. Whilst several authors comment generally on the influence of Union citizenship on the outcome of the EFTA Court's judgment, they do not address the time issue. Thus, Burke \& Hannesson ${ }^{35}$ note that without the CJEU case law on citizenship in EU, "it is doubtful that the EFTA Court would have required this level of protection". Similarly, Arnesen et al. ${ }^{36}$ argue that in Gunnarsson (as well as in the subsequent case of Jabbi) the EFTA Court opted for an interpretation of provisions of Directive 2004/38 at odds with CJEU case law in order to "remedy" the lack of EEA Treaty provisions mirroring Articles 20 et seq. TFEU. The present writer joins these commentators in arguing that even though formally not in contradiction with the Joint Declaration, the EFTA Court's approach is problematic in a context where the Court uses this approach in order to interpret EEA secondary law differently from the relevant secondary EU law, thereby manifestly going beyond both the wording of this law and the relevant CJEU case law.

34 Wennerås, P. (2018). Article 6 Homogeneity, cit., para. 15 .

35 Burke, C., and Hannesson, Ó.Í. (2015). Citizenship by the backdoor? Gunnarsson. Common Market Law Review 52(4), pp. 1111-1133, 1127.

36 The editors (2018). Introduction. The EFTA States, the EEA and the different views on the legal integration of Europe. In: F. Arnesen, F., H.H. Fredriksen, H.H., H.P. Graver, H.P., O. Mestad, O. and C. Vedder C., eds., Agreement on the European Economic Area, cit., pp. 112 , para. 17 . 
As was already indicated above, the present writer considers the EFTA Court's statements about an implied right of exit as such under Directive 9o/365 convincing. At that time, the secondary law relating to movement and residence of economically active persons contained explicit provisions on the right of exit (of the Member State of origin) and of entry (into the host Member State; e.g. Arts. 2 and 3 of Directive 68/36o). ${ }^{37}$ In contrast, the Directives on persons who were not economically active only mentioned the right of residence. It is logical that this implies both a right of exit and a right of entry. However, the EFTA Court disregards the fact that under the Directives that were explicit on this matter, these rights concerned specifically and exclusively the right to cross the border and its technicalities ("simply on production of a valid identity card or passport"). The same is true for Directive 2004/38. In the relevant provisions, there was, and is, no link to equal treatment and freedom of restrictions in other respects.

Moreover, when the CJEU began to develop its case law on measures that could deter Union citizens from making use of their free movement rights, this was in the context of market access rights for the economically active under the Treaty (e.g. Singh, ${ }^{38}$ Bosmann,${ }^{39}$ Kranemann $) .{ }^{40}$ Similarly, when the Court subsequently extended this approach to Union citizenship by introducing a prohibition of restriction, it again linked it to the substance of the right to free movement as stated in the Treaty (e.g. De Cuyper ${ }^{41}$ Rüffler). ${ }^{42}$ It should also be noted that Article 24 of Directive 2004/38 adds to this a right to equal treatment only in respect to further matters, excluding those already covered under other Union law. ${ }^{43}$

37 Council Directive 68/36o/EEC of 15 October 1968 on the abolition of restrictions on movement and residence within the Community for workers of Member States and their families, OJ English Special Edition Series I Chapter 1968(II), p. 485.

38 Court of Justice, judgment of 7 July 1992, Case C-37o/9o, The Queen v Immigration Appeal Tribunal et Surinder Singh, ex parte Secretary of State for Home Department.

39 Court of Justice, judgment of 15 December 1995, Case C-415/93, Union royale belge des sociétés de football association ASBL v Jean-Marc Bosman.

40 Court of Justice, judgment of 17 March 2005, Case C-109/04, Karl Robert Kranemann v Land Nordrhein-Westfalen.

41 Court of Justice, judgment of 18 July 2006, Case C-406/o4, Gérald De Cuyper v Office national de l'emploi.

42 Court of Justice, judgment of 23 April 2009, Case C-544/o7, Uwe Rüffler v Dyrektor Izby Skarbowej we Wroctawiu Ośrodek Zamiejscowy w Watbrzychu.

43 Art. 24(1) of the Directive states: "Subject to such specific provisions as are expressly provided for in the Treaty and secondary law, all Union citizens residing on the basis of this Directive in the territory of the host Member State shall enjoy equal treatment with the nationals of that Member State within the scope of the Treaty. The benefit of this right shall be extended to family members who are not nationals of a Member State and who have the right of residence or permanent residence." Section 2 then provides for certain derogations. 
There is, therefore, a difference between the right to cross the border as a purely technical issue, on the one hand, and the right not be discouraged from making use of a free movement right in a more general sense. Importantly, these different rights are regulated on different levels, and this is where EU law and EEA differ, since the latter in respect to persons who are not economically active includes only one of the two levels, namely that of secondary law.

The EFTA Court is aware of this gap but considers it irrelevant (Gunnarsson, para. 81):

Nor can it be decisive that, in the EU pillar, the [CJEU] has based the right of an economically inactive person to move from his home State directly on the Treaty provision on Union Citizenship, now Article 21 TFEU, instead of on Article 1 of Directive 9o/365 or Article 7 of Directive 2004/ 38 . As the [CJEU] was called upon to rule on the matter only after a right to move and reside freely was expressly introduced in primary law, there was no need to interpret secondary law in that regard [...].

As is stated by some commentators, this is not convincing, not least because of the different nature of the regulation on the two levels. In their careful and extensive annotation of the Gunnarsson judgment, Burke \& Hannesson ${ }^{44}$ note that, up to the point of justification, the EFTA Court interprets the Directives in conformity with a component of the EEA Agreement's free movement provisions, namely the prohibition of discriminations and restrictions in the context of market access (it should be added: rather than movement and residence in a technical sense). The authors consider it rather artificial to do so in the context of a situation falling outside the material scope of these very same free movement provisions (namely because under EU law, it falls under Union citizenship provisions which do not exist under EEA law). The authors also argue - again, convincingly in the present writer's opinion - that it is difficult to reconcile the EFTA Court's use of the exhaustive list of derogations under the Directives with the CJEU and EFTA Court case law on restrictions, where the category of objective justification is open. Against that background, Burke \& Hannesson criticise the EFTA Court's "complete absence of a convincing and explicit methodology", including also the fact that this Court relied on selected CJEU case law only, to the exclusion of other, more recent case law. ${ }^{45}$ This

\footnotetext{
44 Burke, C., and Hannesson, Ó.Í. (2015). Citizenship by the backdoor? Gunnarsson, cit., p. 1125 et seq. 
latter point relates notably to $O$. and $B .{ }^{46}$ which had been handed down before Gunnarsson (and which the European Commission criticised before the EFTA Court). In $O$. and B., the CJEU held that it follows from a literal, systematic and teleological interpretation of Directive 2004/38 that it does not cover situations of a Union citizen returning to the Member State of nationality, or their family members. Instead, the Court found Article 21 TFEU to be applicable (in which context Directive 2004/38 applies by analogy). ${ }^{47}$

Overall, Burke \& Hannesson ${ }^{48}$ note that as a result of the EFTA Court's decision in Gunnarsson, there is now a significant cleavage between the EU and the EEA regime in relation to the interpretation of an identical norm. At the same time, the authors note that had the EFTA Court transposed CJEU case law, EFTA nationals would not have been afforded equal protection in their home states on the basis of EEA law when compared to their counterparts in EU Member States relying on EU law. From that perspective, the authors consider that the conclusion in Gunnarsson would seem justified, even though based on "a rather stretched teleology".

It is submitted that here lies the key to the EFTA Court's approach: rather than opting for a homogeneous interpretation of Article 7 of Directive 2004/ 38 in the sense of following the interpretation in the relevant CJEU case law, the EFTA Court consciously deviates from that interpretation in order to arrive, not at the same interpretation, but rather, through different interpretation, at the same overall level of protection under EU law and under EEA. The fact that this is the Court's guiding star in interpreting Directive 2004/38 becomes evident in the next judgment, in the case of Jabbi, through explicit statements to that effect.

\section{IV.5 The EFTA Court's Decision in Jabbi}

Having been criticised for disregarding the $O$. and $B$. decision of the CJEU in Gunnarsson, the EFTA Court in Jabbi sets out to explain why that judgment could not affect its approach. The EFTA Court begins by acknowledging that under EU law, the right to return of economically non-active citizens together with their family members is based on Article $21 \mathrm{TFEU}$, and that the CJEU had

46 Court of Justice, judgment of 12 March 2014, Case C-456/12 O. v Minister voor Immigratie, Integratie en Asiel and Minister voor Immigratie, Integratie en Asiel $v$ B.

47 More recently, see also Court of Justice, judgment of 5 June 2018, Case C-673/16, Relu Adrian Coman and Others $v$ Inspectoratul General pentru Imigrări and Ministerul Afacerilor Interne.

48 Burke, C., and Hannesson, Ó.Í. (2015). Citizenship by the backdoor? Gunnarsson, cit., p. 1132. 
explicitly rejected the application of Directive 2004/38. The EFTA Court continues in the following manner (Jabbi, para. 66 and 68):

Consequently, an unequal level of protection of the right to free movement of persons within the EEA could ensue. However, if the Court ensures the same level of protection in the EEA, it must explain why the [CJEU's] statement in $O$. and B. regarding the Directive cannot decide the matter. [...] The case at hand must be distinguished from $O$. and $B$. to the extent that that judgment is based on Union citizenship. Therefore, it must be examined if homogeneity in the EEA can be achieved based on an authority included in the EEA Agreement. Such an examination must be based on the EEA Agreement, legal acts incorporated into it and case law.

Having set out its path in this manner and having, further, drawn attention to the preamble of the EEA Agreement, according to which a uniform interpretation and application of the EEA Agreement shall be achieved in full deference to the independence of the courts (Jabbi, para. 70), the EFTA Court recalls its finding in Gunnarsson, namely that Article 7, para. 1, letter b, of Directive 2004/ 38 confers on an EEA national the right to move freely from the home EEA State and to take up residence in another EEA State, that an EEA State may not deter its nationals from moving to another EEA State in the exercise of the freedom of movement under EEA law, including in relation to family members covered by the Directive (Jabbi, para. 75).

Referring to Singh and Eind, ${ }^{49}$ the EFTA Court further recalls that the right to return is protected under EU law. In the latter, in particular, the CJEU recognises that an EU migrant worker may rely on EU law upon returning as an economically inactive person to his home State with a family member from a third country, provided he previously exercised his EU rights. According to the EFTA Court, this reasoning is equally relevant when the person returning is not a former migrant worker, but rather an economically inactive person who has exercised the right to free movement under Article 7, para. 1, letter b, of the Directive. The EFTA Court therefore concludes that, "[w]hen a EEA national makes use of his right to free movement, he may not be deterred from exercising that right by an obstacle to the entry and residence of a spouse in the EEA national's home State. Accordingly, when an EEA national who has availed himself

49 Court of Justice, judgment of 11 December 2007, Case C-291/05 Minister voor Vreemdelingenzaken en Integratie $v$ R. N. G. Eind. 
of the right to free movement returns to his home State, EEA law requires that his spouse is granted a derived right of residence in that State" (Jabbi, para. 77).

From the perspective of the reservation in the Joint Declaration, again, the question should be asked whether the EFTA Court relied on CJEU case law on Union citizenship dating from after 7 December 2007. First, it may be noted that, contrary to the suggestion of the European Commission, the EFTA Court did not refer to McCarthy $I I,{ }^{50}$ handed down in 2014 and recommended by the European Commission as a benchmark. However, this is perhaps understandable in view of the fact that that case concerned an entirely different provision of the Directive, namely Article 35, on measures to refuse, terminate or withdraw any right conferred by the Directive in the case of abuse of rights or fraud, such as marriages of convenience. The Court did, however, rely on Eind, a decision that dates from 10 December 2007. But is it a citizenship case? As stated above, the case involved a former migrant worker who wanted to return home without being economically active there. The CJEU notes that "the right of the migrant worker to return and reside in the Member State of which he is a national, after being gainfully employed in another Member State, is conferred by Community law, to the extent necessary to ensure the useful effect of the right to free movement for workers under Article $39 \mathrm{EC}$ and the provisions adopted to give effect to that right, such as those laid down in Regulation No $1612 / 68$ ", adding that "that interpretation is substantiated by the introduction of the status of citizen of the Union, which is intended to be the fundamental status of nationals of the Member States" (Eind, para. 10). In other words, it may be argued that the real basis of the Court's reasoning in that case remains the free movement for workers, which is a particular aspect of the economic side of Union citizenship. If so, it must be concluded that the Court respected the limits of the reservation.

Again, academic comments on Jabbi do not focus on the temporal aspect of (alleged) Union citizenship case law of the CJEU that the EFTA Court relies on in Jabbi. They rather tend to discuss the EFTA Court's particular approach to the homogeneity principle under EEA law. They note that in interpreting Article 7 of Directive 2004/38, the EFTA Court chose a different approach than the CJEU did in the case of $O$. and $B$., formally distinguishing the case before it from that precedent but in fact openly departing from it. Thus, according to Wennerås, ${ }^{51}$ the EFTA Court held that Directive 2004/38 "could be applied by analogy and gave the applicant the same rights as the [CJEU] had said could

\footnotetext{
50 Court of Justice, judgment of 18 December 2014, Case C-202/13 The Queen, on the application of Sean Ambrose McCarthy and Others $v$ Secretary of State for the Home Department. Wennerås, P. (2018). Article 6 Homogeneity, cit., para. 66.
} 
only be derived from the concept of Union citizenship in Article 21 TFEU. The judgment speaks volumes about how the EFTA Court perceives the principle of homogeneity and the objectives of the EEA Agreement." Following Falch, ${ }^{52}$ Jabbi suggests that the EFTA Court will do much to preserve homogeneity with EU law in its interpretation and application of EEA law, even in situations where the parallel in EU law has been interpreted and applied in light of provisions not made part of the Agreement (i.e. Union citizenship provisions). Franklin ${ }^{53}$ notes that " $t$ the EFTA Court's point seems to be that if one of the aims of the Citizenship Directive was to strengthen pre-existing rights of free movement, then one cannot rely on the introduction of Citizenship to do away with such pre-existing rights in an EEA context. Even if the concept of Citizenship cannot be used to enhance the pre-existing rights which applied under EEA law, it should certainly not be used as an argument to limit rights which were intended to survive. The creative technique opted for by the EFTA Court will therefore presumably be capable of ensuring homogeneity between EEA and EU law in most cases, notwithstanding the contrary impression one might otherwise get from (and perhaps the intention behind) the Joint Declaration."

A final example, Arnesen \& Fredriksen ${ }^{54}$ argue that "[ $\left.\mathrm{t}\right]$ he controversial aspect of Jabbi lies in the fact that the EFTA Court found its break with the case law of the [CJEU] to be supported by the homogeneity principle (as opposed to representing a deviation from it) and, as a result, advocated a more extensive reading of the Citizenship Directive in the EEA law context than in the EU law context."

In this context, again, much depends on the meaning of the homogeneity principle. If homogeneity is understood as requiring, in principle, the same interpretation of a given provision under EEA law as under EU law, then the EFTA Court clearly strayed from it. However, quite clearly, the EFTA Court in the present context does not aim at this type of homogeneity, but rather at homogeneity in view of the same result or the same level of protection. Wennerås ${ }^{55}$ argues that, "[u]nderneath it all lays, it would seem, a conviction that

$5^{2}$ Falch, I. (2018). Article 4 Non-discrimination on grounds of nationality. In: F. Arnesen, F., H.H. Fredriksen, H.H., H.P. Graver, H.P., O. Mestad, O. and C. Vedder C., eds., Agreement on the European Economic Area, cit., pp. 196-208, para. 20.

53 Franklin, C.N.K. (2017). Square Pegs and Round Holes, cit., p. 183.

54 Arnesen, F. and Fredriksen, H.H. (2018). Preamble. In F. Arnesen, F., H.H. Fredriksen, H.H., H.P. Graver, H.P., O. Mestad, O. and C. Vedder C., eds., Agreement on the European Economic Area, cit., pp. 150-179, footnote 100.

Wennerås, P. (2018). Article 6 Homogeneity, cit., para. 66. 
the Contracting Parties wants EEA law to provide the same results as EU law and that it is for the EFTA Court to carry out this task." Following the terminology of Baudenbacher and Fredriksen, Burke \& Hannesson ${ }^{56}$ in the context of Gunnarsson refer to "effect-related homogeneity", stating that this decision represents the first occasion on which the EFTA Court interpreted EEA law to entail more extensive rights than what follows from a settled interpretation of an identical norm of EU law by the CJEU.

Franklin ${ }^{57}$ opines that, "as a result of the EFTA Court's Opinions in both Gunnarsson and Jabbi, it seems as though all rights - both autonomous and derived - contained in EEA rules pre-dating yet furthered in the Citizenship Directive will continue to enjoy the same protection under EEA law today and will continue to be interpreted in conformity with EU developments. It would seem as though almost any case in which the Court of Justice bases its findings on the Citizenship rules of the Treaty, and where aspects of the rights in question find at least some resonance in the provisions of the Directive, might therefore be capable of being followed - by way of analogy."

The present writer would submit that the EFTA Court's approach could be seen to reflect a new, reversed version of the Polydor principle: different contexts of the same provision must lead to different interpretations, where that is necessary in order to achieve the same overall result in terms of the level of peoples' protection. It remains to be seen whether this approach will be confirmed in future decisions such as Campbell ${ }^{58}$ and Norwayv $L^{.59}$

\section{Findings with Respect to the Reservation and Relevance in Other Contexts, Including Notably Brexit}

To return to the reservation in the Joint Declaration with respect to Union citizenship, Pirker ${ }^{60}$ quite rightly called it "in practice hardly ever relevant".

56 Burke, C., and Hannesson, Ó.Í. (2015). Citizenship by the backdoor? Gunnarsson, cit., p. 1117 et seq.

57 Franklin, C.N.K. (2017). Square Pegs and Round Holes, cit., p. 183.

58 E FTA Court, Case E-4/19 Melissa Colleen Campbell $v$ The Norwegian Government, pending at the the time of review of the proofs for the present text.

59 E FTA Court, Case E-2/20 The Norwegian Governmentv L, pending at the the time of review of the proofs for the present text.

6o Pirker, P. (2018). Switzerland and the EEA. In: F. Arnesen, F., H.H. Fredriksen, H.H., H.P. Graver, H.P., O. Mestad, O. and C. Vedder C., eds., Agreement on the European Economic Area, cit, pp. 80-100, para. 32 . 
According to Jay, ${ }^{61}$ this raises the question of how accurate it is to say that citizenship rights do not form part of the EEA Agreement, given that the EFTA Court has essentially assimilated nationality of an EEA/EFTA State with EU citizenship for the purposes of free movement and residence.

However, it remains to be seen whether the reservation would have any meaning in the context of Article 24 of Directive 2004/38, as indicated by the EFTA Court in Clauder. It also remains to be seen what the CJEU will make of the EFTA Court's approach should it be faced with an EEA case on Directive 2004/38 in similar circumstances as those of Clauder, Gunnarsson and Jab$b i$. Will it follow the EFTA Court's interpretation, or will it go in a different direction, adhering to its own, previous EU case law, also in the overall different context of the EEA? Or will it follow a middle path, opting for an EEAspecific interpretation that is different from that by the EFTA Court? In this context, it will be remembered that the European Commission had urged the EFTA Court to depart from $O$. and B., apparently aiming at the judicial dialogue between the two Courts and possibly hoping that an interpretation by the EFTA Court along the lines suggested by it would, subsequently, lead the CJEU to take the same approach when dealing with Directive 2004/ 38 in the EEA context. As Baudenbacher ${ }^{62}$ notes, the CJEU has shown itself willing to enter into a dialogue with the EFTA Court and in some instance even to reconsider and to adjust its case law in the light of the E FTA Court's jurisprudence.

Finally, there is the question of what all of this could mean in other contexts, i.e. in the legal relations of the EU with other non-Member States. ${ }^{63} \mathrm{In}$ this respect, different legal regimes must be distinguished. For example, under the Ankara Agreement between the EU and Turkey, ${ }^{64}$ Directive 2004/38 is not part of the common legal acquis. At the same time, it is established CJEU case law that "the principles enshrined in the Treaty articles relating to freedom of movement for workers must be extended, as far as possible, to Turkish nationals who enjoy rights under the EEC-Turkey Association", and that the law

61 Jay, M.A. (2012). Homogeneity, the free movement of persons and integration without membership: mission impossible?, cit., p. 88.

62 Baudenbacher, C. (2008). The goal of homogeneous interpretation of the law in the European Economic Area, cit., p. I-24 et seq.

63 See Tobler, C. (2016). One of Many Challenges After ,Brexit'. The Institutional Framework of an Alternative Agreement - Lessons from Switzerland and Elsewhere? Maastricht Journal of European and Comparative Law, 575-594.

64 Agreement of 1963 establishing an Association between the European Community and its Member States, of the one part, and the Republic of Turkey, of the other part, OJ 1973 C $113 / 1$ (as amended). 
of the Ankara Agreement must be interpreted by analogy with EU Treaty and secondary law (e.g. Ziebell, ${ }^{65}$ para. 58). Against that background, the applicant in the case of Ziebell argued that Article 28 of Directive 2004/38, which establishes a system of protection against expulsion measures which is based on the degree of integration of the person in question in the host Member State, should apply also in the context of the agreement. The CJEU disagreed, stating that it is "the very concept of citizenship [which] justifies the recognition, for Union citizens alone, of guarantees which are considerably strengthened in respect of expulsion, such as those provided for in Article 28(3)(a) of Directive 2004/38" (Ziebell, para. 73).

Another example relates to the EU-Swiss agreement on the free movement of persons (FMP). ${ }^{66}$ In terms of movement, residence and family reunification, this agreement is based on secondary EU law that predates Directive 2004/38. Whilst the EU desired the incorporation of that Directive into the acquis of the agreement, the Swiss Government resisted. So far, this has been possible because the agreement does not provide for a system of dynamic updating in line with the evolving EU law on which the agreement is based. However, the FMP is part of a package of market access agreements for which the EU has demanded the introduction of a new institutional system, including, among others, a dynamic system of updating. Whilst Switzerland agreed to enter into negotiations on a renewed institutional system for the relevant agreements as well as for any future market access agreements, the Federal Government has aimed at leaving the incorporation of Directive 2004/38 out of the scope of the negotiations. In this respect, it has not been successful so far: The draft text for an Institutional Agreement resulting from the negotiations as they stood at the end of November $2018^{67}$ does not contain any limiting provisions with regard to Directive 2004/38. In fact, the draft text does not mention the Directive at all, with the consequence that it falls in principle under the new dynamic updating mechanism. It would then be up

65 Court of Justice, judgment of 8 December 2011, Case C-371/o8, Nural Ziebell v. Land Baden-Württemberg.

66 Agreement of 21 June 1999 between the European Community and its Member States, of the one part, and the Swiss Confederation, of the other, on the free movement of persons, OJ 2002 L 114/6 (as amended).

67 Accord facilitant les relations bilaterales entre l'Union européenne et la Confédération Suisse dans les parties du marché intérieur auxquelles la Suisse participle, original French draft text of 23 November 2018, available at https://www.eda.admin.ch/dam/ dea/fr/documents/abkommen/Acccord-inst-Projet-de-texte_fr.pdf. See generally e.g. Epiney, A. (2018). Der Entwurf des Institutionellen Abkommens Schweiz - EU. Jusletter 17 
to the contracting parties to agree within the framework of the updating procedure whether Directive 2004/38 should be incorporated into bilateral law as a whole or only in part. 68

Much earlier, after the EFTA Court's decision in the case of Wahl had been handed down, the present writer suggested that, given the Court's statements about the limits of the incorporation of the Directive into the EEA Agreement, a limited incorporation of the Directive could also be useful for Switzerland, namely incorporation of the Directive minus its Union citizenship elements. ${ }^{69}$ However, the EFTA Court's subsequent case law, as discussed in this contribution, has shown that for such a carve-out to be effective, it would be wise to frame it in much more explicit terms.

This, then, would also be the lesson in the context of Brexit in the - though at present admittedly unlikely - event that the UK and the EU, following the former's withdrawal from the Union, should agree on a future legal relationship including some form of free movement of persons based on EU rules. Again, should the UK wish for a carve-out of specific Union citizenship elements, it would have to insist on a specific and unambiguous regulation of the matter.

Alternatively, should the UK decide to (re-)join the EEA - though also unlikely at the time of writing - then it would find that free movement of persons under EEA is to a very large extent the same as under EU law, in spite of the absence of Union citizenship under EEA law. Indeed, the only clearly established difference is the presence, in the EEA Agreement only, of a permanent safeguard clause. Article 112 EEA provides:

1. If serious economic, societal or environmental difficulties of a sectorial or regional nature liable to persist are arising, a Contracting Party may unilaterally take appropriate measures under the conditions and procedures laid down in Article 113 .

December 2018, Ambühl, M. and Scherer, D.S. (2019). Zum Entwurf des Institutionellen Abkommens. Jusletter 4 February 2019, and Tobler, C. and Beglinger, J. (2020). Tobler/ Beglinger-Brevier zum Institutionellen Abkommen Schweiz-EU. Online publication, available via www.brevier.eur-charts.eu.

68 On this issue, see in particular Epiney, A. and Affolter, S. (2019). Das Institutionelle Abkommen und die Unionsbürgerrichtlinie. Jusletter 11 March 2019; also Tobler and Beglinger. Tobler/Beglinger-Brevier, cit., as of question 44.

69 Tobler, C. (2013). Bikers Are(n't) Welcome, cit., p. 254; subsequently also Tobler, C. (2015). Auswirkungen einer Übernahme der Unionsbürgerrichtlinie für die Schweiz - Sozialhilfe nach bilateralem Recht als Anwendungsfall des Polydor-Prinzips. In: A. Epiney, A. and T. Gordzielik, T., eds., Personenfreizügigkeit und Zugang zu staatlichen Leistungen / Libre circulation des personnes et accès aux prestations éta-tiques, cit., pp. 55-82. 
2. Such safeguard measures shall be restricted with regard to their scope and duration to what is strictly necessary in order to remedy the situation. Priority shall be given to such measures as will least disturb the functioning of this Agreement.

3. The safeguard measures shall apply with regard to all Contracting Parties.

This EEA law clause - which has been used only once it its history, namely by Liechtenstein before it secured a special deal under the EEA that limits its obligation to let other EEA nationals settle on its territory $-{ }^{70}$ gives a certain leeway to the contracting States which is not available under EU law, if only in special circumstances. It is obvious that this is far from letting the States control the movement of persons based on their own, unilateral decision, as has been the aim of the recent UK governments for the time post-Brexit. In fact, to be completely "free" of EU law-related ramifications to the movement of persons, both on the substantive and on the institutional level, requires a common regime that makes no use whatsoever of substantive EU law concepts. Only in that case, will no issues of parallel interpretation arise.

70 See Tobler, C. (2015). Schutzklauseln in der Personenfreizügigkeit mit der EU. Jusletter 16 February 2015 . 